\title{
Father Involvement, Gender Perception and Children's Gender Stereotypes
}

\author{
Sevcan Yağan Güder ${ }^{1, *}$, Seda Ata $^{2}$ \\ ${ }^{1}$ Early Childhood Education Program, İstanbul Kültür University, İstanbul, Turkey \\ ${ }^{2}$ Early Childhood Education Program, Muğla Sitkı Koçman University, Muğla, Turkey
}

Copyright $\bigcirc 2018$ by authors, all rights reserved. Authors agree that this article remains permanently open access under the terms of the Creative Commons Attribution License 4.0 International License

\begin{abstract}
The main purpose of this research is to examine the relationship between fathers' involvement, their gender perceptions, and the gender stereotypes of children. A relational survey model was used in this research. The sampling of the research is composed of 151 randomly selected 60 to 72-month-old children, who attended preschools in the centre of Muğla province in Turkey, and their fathers. As data collecting tools, Demographic Information Form, Father Involvement Scale (60), Perceptions of Gender Scale (3), and Gender Stereotypes Assessment Instrument (65) were utilized. According to research results, fathers' equalitarian perspective regarding gender increases their involvement levels. On the other hand, it was determined that the gender of the child and the age of their father play a significant role in their father's involvement. It was determined that there is a significant positive relation between the gender stereotypes of the child and their father's arbitrary engagement, which is one of the sub-dimensions of the father involvement scale. It was also discovered that while the fathers' income is significant in the gender stereotypes of children; factors like their occupation, age, gender perceptions, and their involvement levels are not.
\end{abstract}

Keywords Father Involvement, Gender Perceptions, Gender Stereotypes, Father, Child

\section{Introduction}

Though it is generally possible to make reference to many factors in children's social behaviours, interests and tendencies, parents are considered to be the most important influence (42). Although responsibilities concerning childcare vary inter-culturally, the mother has been generally seen as the primary individual responsible for such influences. According to this view, the mother's role is universal and unique, and there is an approach which unequivocally puts the mother's role in an essential place in terms of the development of their children (5). Still, there are some societies in which the fathers have more social and legal rights and responsibilities over their children $(7 ; 57)$. Furthermore, researches on the fathers' role in child development have gained momentum in the last thirty years $(19 ; 44)$. The alternative roles of a father have been a question of debate among people, who value traditional parental gender roles and expectations (38). Fathers are fundamental figures in supporting every developmental aspect of their children. For instance, it was determined that babies who get intensive attention and care from their fathers in the first months of their lives are more willing to communicate with their environment (2), and babies whose fathers play with them, communicate with them, and engage in nursing activities are better problem solvers and have a higher IQ by the time they are approximately three years old $(21 ; 81)$. It was also determined that babies whose fathers participate in their care are more securely attached to them (16). Moreover, they are more eager and curious to explore their environment, and they give more stable reactions to new stimuli (50). It was stated that when a father establishes an early and positive connection with his child, it reduces the chance of cognitive delays in the child (10).

It has been established that fathers' involvement and attention positively affects the academic success of their children as well. In an similar fashion, it is claimed that compared to children with no paternal participation, preschool children's readiness for was was better if they had fathers who participated in their development apparently, they were more patient, and it was easier for them to cope with the stress and difficulties the faced at school (69). Higher father participation levels are shown to directly affect the children's rapport behaviours (27). Children display less problematic behaviours (15), attend higher education for a longer period of time (28), have better mental health $(9 ; 20)$, and exhibit positive social behaviours at approximately the age of three (37). Additionally, it was confirmed that the children, who receive parental participation, develop a more positive 
social attitude towards their siblings, show less negative emotional reactions while playing with their peers, experience less tension in their interactions with other children, and try to resolve conflicts on their own rather than with the help of their teacher $(63 ; 73)$. When fathers' conversations with their little children consist mostly of "what" and "where" questions, these dialogues encourage children to form longer sentences and to use a more diverse vocabulary (56). Similar to the mother's love, the father's love also significantly influences a baby's condition of psychological welfare and health as well as his/her attitudes and psychological problems (55).

Father involvement is also influential on children's physical health. A father's contribution to the baby's physical health begins with the pregnancy. When fathers support their spouses emotionally, it increases chances that the mothers will feel better, experience a better post-partum period, and have better mental health. Therefore, this relationship supports the mental and physical development of the baby (31). For instance, children whose fathers are absent from home are more likely to be obese compared to those children whose fathers spend more time with them (62).

It is obvious that positive paternity attitudes contribute to the social-emotional, cognitive, linguistic and physical developments of children (e.g. 59; 66; 67). Moreover, it has been determined that fathers affect their children's gender role perceptions, too. For example, compared to mothers, fathers give more clear messages to their children about how they perceive gender $(23 ; 47)$. These messages appear both verbally and behaviourally. To exemplify, it was asserted that children, whose parents both take responsibility in house chores, have less stereotypes about domestic responsibilities compared to the children whose fathers do not take responsibility in housework $(78 ; 77)$.

Particularly in early childhood, parents' effect on the development of their children's gender roles is vital (45). In this context, parents' stereotypes concerning gender are closely associated with children's attitudes towards gender This relation has been revealed in numerous studies (e.g 68). In many cultures, boys may be considered more valuable, and different rules might seem to apply for boys and girls $(23 ; 42)$. As well as the present society's scheme of gender roles, parents' own values and beliefs fundamentally shape their parental attitudes (64). It was concluded that children with traditional parents display more attitudes of gender stereotypes than children whose parents hold egalitarian views (26).

Just as fathers' stereotypes concerning gender affect their children's stereotypes, they also influence their own fatherhood attitudes and paternal participation. To illustrate this point, Radin and Harold Goldsmith (52) stated in their studies that the fathers' flexible views regarding gender roles increase the fathers' parental participation. On the other hand, Bonney, Kelley and Levent (8) and Unlu Cetin (72) expressed in their studies that the fathers' attitudes on gender roles play an important role in their participation in child care. The fathers' liberal views enhance their sympathy, warmth and attentiveness towards his family too (32).

Both in studies on gender and in documented research that examine the effects of parents on their children's social and emotional developments, it was observed that parent sample mostly consisted of mothers (e.g. 22) and that fathers took part to a noticeably lesser extent (e.g. 18). That is to say, it was determined that generally there are more research results about mothers in parental studies (48). In Zeybekoglu's (82) research based on scanning the related body of literature, it is stated that the studies carried out on the factors that determine the attitudes and behaviours concerning fatherhood are inadequate, and that further studies on this topic were needed. Yet, it can be said that a father's love and attention are as important as a mother's love and attention in terms of the child's psychological well-being, and in terms of the children not exhibiting behavioural problems (24). Therefore, with reference to the fact that there is a necessity for further research on the father involvement and father-child relations, the purpose of this research is to examine the gender perceptions of the fathers, father involvement, and the relation between children's gender stereotypes.

\section{Materials and Methods}

\subsection{The Research Model and Study Group}

The research was conducted in accordance to a relational survey model. Participants of the research were 60 to 72 -month-old children attending preschools in the Mugla province and their fathers. Upon examining the demographic information obtained on the participants, it was determined that of the 151 children, 74 of them were girls, 77 of them were boys. It was also deduced that most of the children were older than 60 months $(f=104)$. The ages of the fathers who participated in this research were concentrated to a large extent on the ages between 31 and 45. 61 of the 151 fathers were high school graduates, and 36 of them had a bachelor's degree. It was observed that most of the fathers were employed as workers $(f=82)$, were married from 6 to 10 years $(\mathrm{f}=88)$, and had one or two children ( $\mathrm{f}=127) .66 .9 \%$ of the fathers, which is a large majority, stated that they spend at most 3 hours with their children on a daily basis.

\subsection{The Data Collecting Tools}

In this research, An Information Form, Father Involvement Scale, Perception of Gender Scale, and 
Gender Stereotypes Assessment Instrument were utilized.

\subsubsection{Father Involvement Scale (FIS)}

Developed by Simsıkı and Şendil (60), the Father Involvement Scale (FIS) was developed with the purpose of measuring what kind of activities the fathers with children between 3 to 6 years old participated in and in what frequency. Questions in the FPS targeted behavioural patterns and were answered through a five-point likert scale. The option "always" was given 5 points, "mostly" 4 points, "sometimes" 3 points, "rarely" 2 points and "never" was assigned 1 point. Both separate points for each dimension and a total point tally were obtained. When the fathers obtained high scores on the scale, it indicates that their paternal participations are high.

\subsubsection{Perception of Gender Scale}

This scale was developed by Altınova and Duyan (3), and its validity and reliability were checked. This scale was specifically designed to be applied to adults. It has the quality to measure an individual's attitudes concerning how they perceive gender roles on various areas. The scale is composed of 25 items in total. Each is given points from 1 to 5 , which indicate the options "strongly agree," "agree," "neutral," "disagree" and "strongly disagree." Some items are reversely pointed while calculating a total scale point $(2 \mathrm{nd}, 4 \mathrm{th}, 6 \mathrm{th}, 10 \mathrm{th}, 12 \mathrm{th}$, 15 th, 16th, 17th, 18th, 19th, 20th, 21st, 24th and 25th items were reversely pointed.). The minimum point to be obtained from this scale is 25 , and maximum is 125 points. If the participant scored a high point this indicates that his/her gender role perceptions are more differentiated, while a low score indicates that his/her gender role perceptions shows more fluidity. Analyses concerning internal consistencies of the scale were measure by testing it on 443 people. And the concluding Cronbach Alpha internal consistency coefficient was calculated as .872 .

\subsubsection{Gender Stereotypes Assessment Instrument}

"Gender Stereotypes Assessment Instrument" was developed by Ş1vgın (65) with the aim of determining the gender stereotypes of 60 to 72 -month-old children. In this measurement tool, there are 43 items and 4 dimensions in total. The assignments/tasks dimension is composed of 9 items, the occupations dimension is composed of 17 items, the toys dimension is composed of 10, and the games category is composed of 7 items. The reliability of each of the scale's items is calculated as 0.82 . Of the 9 items in the assignments/tasks dimension of the scale, 6 of the items involve feminine roles, and 3 of them involve masculine roles. In the occupations dimension, 7 of the items involve feminine roles and 10 of them involve masculine roles. The toys sub-dimension includes 4 gender-stereotypical items for girls and 6 for boys. In the games category, there are 3 game items for girls and 4 items for boys. In the gender stereotypes measuring tool, each item has three answers. These answers are "Woman," "Man" and "Woman and Man" in "Assignments/Tasks and Occupations" sub-dimensions. In the toys and games sub-dimensions, the answers are "Girl," "Boy" and "Girl and Boy." In the measuring tool, answers "Woman and Man" and "Girl and Boy" in the toys and games sub-dimensions do not reflect gender stereotypes. Only the answers "Woman" or "Man" (or "Girl," "Boy") reflect gender stereotypes. The measuring tool can be evaluated separately for each item. However, the total point can be calculated by giving 1 point for "Woman and Man" answer and 0 points for a "Woman" or "Man" answer for each item. While high scores reflect an androgynous feature, low scores indicate low gender stereotypes.

\subsection{Data Analysis}

In the statistical analysis of the data, relationship between children's gender stereotypes and their fathers' gender role perceptions and paternal participation was examined. To determine the relation between variables, The Pearson product-moment correlation coefficient was utilized. A multiple regression analysis was used in order to find out whether or not the gender stereotypes of the children could be predicted by their fathers' gender role perceptions and paternal participation.

\section{Finding}

Correlation analyses were carried out to define the relationships between the fathers' gender perceptions, a child's gender stereotypes, and the Father Involvement Scale and its sub-dimensions. Then, the correlation coefficients were calculated. 
Table 1. Correlations of the fathers' gender perceptions,a child's gender stereotypes, and the Father Involvement

\begin{tabular}{|c|c|c|c|c|c|c|}
\hline & & $\begin{array}{c}\text { Fathers' Gender } \\
\text { Perceptions }\end{array}$ & $\begin{array}{c}\text { Child's Gender } \\
\text { Stereotypes }\end{array}$ & $\begin{array}{c}\text { Father Involvement } \\
\text { Scale }\end{array}$ & $\begin{array}{c}\text { Arbitrary } \\
\text { Engagement }\end{array}$ & $\begin{array}{c}\text { Attention and } \\
\text { Affection }\end{array}$ \\
\hline \multirow{2}{*}{ Fathers' Gender Perceptions } & $\mathrm{r}$ & \multirow[t]{2}{*}{ 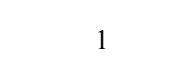 } & .002 & $.187^{*}$ & .157 & .141 \\
\hline & $\mathrm{p}$ & & .978 & .022 & .054 & .084 \\
\hline \multirow{2}{*}{ Child's Gender Stereotypes } & $\mathrm{r}$ & .002 & \multirow{2}{*}{1} & .157 & $.191^{*}$ & .021 \\
\hline & $\mathrm{p}$ & .978 & & .055 & .019 & .798 \\
\hline \multirow{2}{*}{ Father Involvement Scale } & $\mathrm{r}$ & $.187^{*}$ & .157 & \multirow{2}{*}{1} & $.944^{* *}$ & $.751^{* *}$ \\
\hline & $\mathrm{p}$ & .022 & .055 & & .000 & .000 \\
\hline \multirow{2}{*}{ Arbitrary Engagement } & $\mathrm{r}$ & .157 & $.191^{*}$ & $.944^{* *}$ & \multirow{2}{*}{1} & $.559^{* *}$ \\
\hline & $\mathrm{p}$ & .054 & .019 & .000 & & .000 \\
\hline Attention and Affection & $\mathrm{r}$ & .141 & .021 & $.751^{* *}$ & $.559^{* *}$ & 1 \\
\hline \multirow{3}{*}{ Basic Care } & $\mathrm{p}$ & .084 & .798 & .000 & .000 & \multirow{2}{*}{$.508^{* *}$} \\
\hline & $\mathrm{r}$ & $.196^{*}$ & .156 & $.883^{* *}$ & $.787^{* *}$ & \\
\hline & $\mathrm{p}$ & .016 & .056 & .000 & .000 & .000 \\
\hline
\end{tabular}

$* \mathrm{p}<0.05$

According to this, the father's gender perceptions have a positive relation with his involvement scale to a significance level of $18.7 \%$, and his basic care has a significance level of $19.6 \%$.

There is a significant positive relation at a $19.1 \%$ level between a child's gender stereotypes and their father's arbitrary engagement with them.

The father involvement scale has a significant positive relation with its sub-dimension arbitrary engagement category being at a $94.4 \%$ level; with its sub-dimension of attention and affection at a $75.1 \%$ level; with its sub-dimension of basic care at a $88.3 \%$ level.

The arbitrary engagement sub-dimension has a significant positive relation with the fathers' parental attention and affection categories, displaying a 55.9\% level, and with the fathers' basic care on the level of $78.7 \%$.

There is a significant positive relation of $50.8 \%$ between the fathers' attention \& affection and basic care.

The regression model was created, in which paternal participation was regarded as the dependent variable while the child's gender, and their father's occupation, age, income and gender role perceptions were regarded as independent variables, and its test results of the model are given on the table.

Table 2. Regression model for child's gender, and their father's occupation, age, income and gender role perceptions on father involvement

\begin{tabular}{|c|c|c|c|c|c|}
\hline & \multirow{2}{*}{ Model } & \multicolumn{2}{|c|}{ Nonstandard Coefficients } & \multirow{2}{*}{$\begin{array}{c}\text { Standard } \\
\text { Coefficients } \\
\text { Beta } \\
\end{array}$} & \multirow[t]{2}{*}{$\mathrm{T}$} \\
\hline & & $\mathrm{B}$ & Std. Error & & \\
\hline \multirow{6}{*}{$\begin{array}{l}\text { Father Involvement Scale } \\
\qquad \begin{array}{c}\mathrm{F}=5.735 ; \mathrm{p}=0.000^{*} \\
\mathrm{R}^{2}=0.165\end{array}\end{array}$} & Invariant & 133.753 & 15.194 & & 8.803 \\
\hline & Child's gender & 8.724 & 3.618 & .188 & 2.411 \\
\hline & Father's occupation & -1.515 & 1.364 & -.088 & -1.111 \\
\hline & Father's age & -6.543 & 1.769 & -.288 & -3.699 \\
\hline & Father's income & .910 & .926 & .079 & .982 \\
\hline & Father's gender perception & .208 & .114 & .145 & 1.820 \\
\hline
\end{tabular}

${ }^{*} \mathrm{p}<0.05$

According to the test results, it was determined that the regression model is significant $(\mathrm{F}=5.735 ; \mathrm{p}<0.05)$. Upon seeing that the model is significant, the significance level of the coefficients of the parameters in the model was examined. Accordingly, it was observed that while the temporarily invariable a child's gender and their father's age in the model were significant, the father's occupation, income and gender perceptions were insignificant. Equation of the model is as follows:

Father's Paternal Participation Scale $=133.753+0.188 *($ Gender $)-0.288 *($ Father's age $)$

It was observed that the child's gender and the father's age significantly predict the fathers' extent of parental participation. While participation levels of fathers who have boys are higher, when the father's age is higher, it leads to a negative prediction of the levels of his participation.

The regression model in which the children's gender stereotypes are regarded as dependent variables, while the child's gender, the father's occupation, age, income and gender role perceptions are regarded as independent variables was tested.

The regression model was repeated by including the Father Involvement Scale undivided and with its separate sub-dimensions. 
Table 3. Regression model for child's gender, the father's occupation, age, income and gender role perceptions and father involvement on child's gender stereotypes

\begin{tabular}{|c|c|c|c|c|c|}
\hline & \multirow{2}{*}{ Model } & \multicolumn{2}{|c|}{ Nonstandard Coefficients } & \multirow{2}{*}{$\begin{array}{c}\text { Standard Coefficients } \\
\text { Beta }\end{array}$} & \multirow{2}{*}{$\mathrm{t}$} \\
\hline & & B & Std. Error & & \\
\hline \multirow{5}{*}{$\begin{array}{l}\text { Child's gender stereotypes } \\
\qquad \begin{array}{c}\mathrm{F}=2.184 ; \mathrm{p}=0.048^{*} \\
\mathrm{R}^{2}=0.083\end{array}\end{array}$} & Invariable & 13.046 & 8.474 & & 1.540 \\
\hline & Gender of the Child & 0.470 & 1.661 & 0.024 & 0.283 \\
\hline & Father's Occupation & -1.132 & 0.617 & -0.153 & -1.835 \\
\hline & Father's Age & -0.410 & 0.833 & -0.042 & -0.492 \\
\hline & Father's Income & 0.906 & 0.419 & 0.184 & 2.166 \\
\hline \multirow{11}{*}{$\begin{array}{l}\text { Child's gender stereotypes } \\
\qquad \begin{array}{c}\mathrm{F}=1.827 ; \mathrm{p}=0.077 \\
\mathrm{R}^{2}=0.093\end{array}\end{array}$} & Father's Gender Role Perceptions & -0.055 & 0.052 & -0.090 & -1.058 \\
\hline & Father Involvement Scale & 0.051 & 0.037 & 0.119 & 1.357 \\
\hline & Invariable & 17.156 & 9.253 & & 1.854 \\
\hline & Gender of the Child & 0.279 & 1.703 & 0.014 & 0.164 \\
\hline & Father's Occupation & -1.010 & 0.632 & -0.136 & -1.599 \\
\hline & Father's Age & -0.438 & 0.846 & -0.045 & -0.518 \\
\hline & Father's Income & 0.841 & 0.426 & 0.170 & 1.975 \\
\hline & Father's Gender Perceptions & -0.051 & 0.052 & -0.083 & -0.966 \\
\hline & Father's Arbitrary Engagement & 0.137 & 0.112 & 0.171 & 1.228 \\
\hline & Father's Attention and Affection & -0.119 & 0.146 & -0.081 & -0.814 \\
\hline & Father's Basic Care & 0.034 & 0.192 & 0.025 & 0.177 \\
\hline
\end{tabular}

$* \mathrm{p}<0.05$

In the regression model in which the father's parental participation is included undivided, it was determined that the model is significant $(\mathrm{F}=2.184 ; \mathrm{p}<0.05)$. The independent variables influence $8.3 \%$ of the dependent variable. Upon examining the coefficient's significance levels in terms of the parameters in the model, it can be observed that only the income variable is significant. In this case, the equation of the model is as follows:

Child's gender stereotypes $=0.184 *$ (Father's income $)$

In the model in which the sub-dimensions of the Father Involvement Scale are included separately rather than the scale being undivided, the results of the regression model are not significant.

\section{Result and Discussion}

The first finding obtained by this research is that the relation between the father's gender perceptions and participation is significantly positive. In other words, as the fathers consider the gender concept to be more egalitarian, their parental participation increases. Studies highlighting the relation between the father involvement and gender perceptions are included in the literature $(8 ; 32$; $36 ; 52 ; 72)$. In the relevant studies it is emphasized that the fathers' perspectives on gender play an important role in their involvement, and the fathers' more androgynous roles make them more likely to participate in parenthood more frequently. In the heart of the existence of a relation between the fathers' involvement and gender perceptions lies the fact that the mother is regarded as the primary constituent for the responsibilities related to child care, because, in that social perspective, it is the mother who is primarily responsible for the care, education and development of their child. This manifests itself as a social role shaped for mothers and women. According to Lamb \& Lewis, the fathers' positive or negative perceptions can be explained through their social factors, rather than biological ones (Qtd: 36). For instance, studies by Storey, Walsh, Quinton, \& Wynne-Edwards (61) have measured fathers' and mothers' hormone concentrations and responses for their baby's stimuli before and after birth. Two blood samples before and after the birth of the baby were taken, and then spouses were exposed to the infants' auditory, visual and olfactory clues (situational response test). It was determined that men and women have similar degrees of variations in hormone levels, including higher prolactin and cortisol concentrations in the period just before the birth and prenatal gender steroid concentration variations (testosterone and estradiol) were similar as well.

It was observed that there is a correlation in hormone concentrations both in mothers and fathers; yet, men who are not fathers did not go through those hormonal changes. In accordance with these results obtained from the research, it can be said that fathers have as much hormonal impulse as mothers in nursing activities. Therefore, the actual factor, which prevents fathers from giving this nursing service, is not biological but social. To exemplify, many girls are exposed to toys and behavioural models which will try to make them adopt femininity and maternity roles according to what their parents perceive 
these to be from the moment they are born, and a similar type of approach is adopted for many boys too. There are numerous studies related to the idea that children make toy and game preferences, which are "suitable for their genders" $(17 ; 40 ; 77 ; 79 ; 80 ; 74)$, and the idea that parents play a major role in the formation of these preferences $(1$; $25 ; 29 ; 30 ; 51 ; 58 ; 78 ; 76)$.

Growing up with the behavioural patterns and models mentioned here, children might think that only the mother is supposed to do the nursing activities. On the other hand, according to Karre (36) for instance, the long period of time mothers spend with their children may provide them with more experience, and accordingly may lead to the wrong impression that they are naturally good at nursing.

Alternatively, Lindsey (41) states that mothers might exhibit a series of behaviours, which might prevent fathers from attempting to nurse the child. These kinds of social factors can hinder fathers from their parental participation, and most of these factors are related to gender stereotypes. Thus, this kind of gender gap in terms of housework is related to traditional gender ideologies.

In a similar fashion, it was determined that there is a significant positive relation between the basic care, one of the subscales of the Father Involvement Scale, and the gender perception of the father. It was observed that fathers' positive views concerning gender equality affect their participation in the basic care of their children. In the literature, there are research findings on the idea that fathers' nursing activities and their perspectives on gender are related $(54 ; 71)$. The fact that fathers do not see themselves primarily responsible in the care and nourishment of their children is associated with their perceptions of gender roles. It was determined that the Father's Involvement Scale has a significant positive relation with its own sub-dimension, entitled arbitrary engagement, at a $94.4 \%$ rate; with attention and affection at a $75.1 \%$ rate, and with basic care at a $88.3 \%$ rate. In this case, it can be deduced that the fathers participate primarily in the arbitrary engagement sub-dimension, and secondly in basic care, then thirdly in attention and affection. Similarly Kuruçırak (39) maintained in her studies that fathers' involvements in their children's physical care are minimal, while their participation in their attention and game activities are maximal.

Upon examining the research findings about the factors which affect fathers' involvement, their occupation, income and perceptions of gender were identified as variables which do affect their participation. Not many studies are available in the literature about the income levels of fathers. However, some studies state that the income level of the father affects their paternal participation, while others studies state that it does not. On this point, how the father regards parental participation is important. For instance, if the father thinks traditionally that his role is to provide financially for his child and family, he may think that he participates enough and that he fulfills role of fatherhood already (Becker, 1991; Qtd:
11).

On the other hand, fathers who are unable to provide financial support might paternally participate by undertaking other parenthood responsibilities like nursing (34). In other respects, the finding that a father's occupation does not affect his participation (which is a result concluded from the study) conflicts with Parke's study (2002). In his study, Parke (2002) states that the fathers who have received an education for a long period of time are more satisfied with their jobs, and that there is a positive relation between the fathers' job satisfaction, parental participation and their perception of the paternal roles (Qtd: 11).

It was determined in this study that the gender of the child and age of the father affect the fathers' level of involvement. The fathers particularly show more involvement with their sons. Kuruçrak (39) claims that fathers who have daughters hold more positive perceptions about their roles as a father. On the other hand, Raley and Bianchi (53) have stated in their studies that in American families, fathers invest more in their sons and spend more time with them. Studies have also shown that the fathers show more participation with their son rather than with their daughters $(12 ; 13 ; 43)$. This preference may be related to the fathers' belief that they can do many more things with their children of the same gender and that they have the knowledge and skills to establish a far better relationship with their sons rather than their daughters (11). In this respect, during the period which covers, according to Freud, the ages between 3 and 6 (which he called the phallic stage and which includes their preschool years) boys who identify with their fathers started to gain masculine characteristics, and girls who identify with their mothers began to acquire feminine characteristics (14). In this context, many families may think that bonding and identification processes are important in the child's development of gender roles, and that boys should spend more time with their fathers and girls with their mothers, especially during this period. Yet, Freud's hypothesis which claims that identification takes place at the ages of 4 and 5 cannot be proven for the reason that gender-based behaviour can actually be observed among children at much younger ages (6).

On the other hand, another finding of this research is that as the fathers grow older, their involvement rates decrease. This finding can be interpreted as the young fathers' superior parental participation. However, Gultekin Akduman and Turkoglu (33) determined in their studies that the fathers who are 41 or older scored higher points for perception of the fatherhood role. Trindade and Menandro (70) stated in their studies that the young fathers' possibility of adopting traditional gender roles in their children's care is higher, and this negatively affects their father involvement levels. Conversely, older fathers may have been less associated with the traditional stereotypes of fatherhood behaviours and show a higher level of parental participation (49). 
Another result of this study is that there is a significant positive relation between the gender stereotypes of the child and his fathers' arbitrary engagement, which was one of the sub-dimensions of Father Involvement Scale. As father performs social activities with his child, spends time with his child and enjoys being with his child, this contributes to the child's perceptions related to gender equality. Finally, upon examining the findings on the factors that affect the children's gender stereotypes, it was discerned that the father's occupation, age, perception of gender, and father involvement are not significant in their children's gender stereotypes; only the father's income is effective on a significant level. In the literature, it is common to see that children, similar to adults, have stereotypical thoughts concerning gender $(4 ; 30 ; 35 ; 46$; $51 ; 78 ; 77 ; 75)$. Yet, the finding that the fathers' income level is significant in their children's gender stereotypes can be interpreted as the influence of the idea that as income level increases, the possibility that the child can encounter families of various cultures and structures increases; that fact that he/she is more likely to have more experience by visiting various countries and cities, and to be exposed to an environment rich in terms of these related stimuli may change their perspectives. Therefore, it is possible to say that the possibility of seeing more positive role models regarding gender equality increases, and this lead them to overcome their stereotypes. Particularly in preschool children, seeing a role model is of a crucial factor. For instance, Yagan Guder (77) states in her research those children whose parents both take responsibility in the housework embraces stereotypes less than those children whose fathers do not take any housework responsibility. Also, Murray (46) has stated that children raised in traditional families are more stereotypical than those raised in more egalitarian families. On the other hand, Yagan Guder stated in her doctorate study that having a role model play an important role in the development of children's stereotypical ideas. Regarding the activities carried out as part of this study concerning role models, some of the children's opinions are as follows: 'Women can't be mechanics, because I have never seen a woman mechanic;' 'Both men and women can be bus drivers. I saw a woman bus driver when I went out with my mum;' 'Women cannot be construction workers'; 'I saw one on the television, there was a woman constructor.' These examples indicate that seeing a model is of a great importance in the formation of children's stereotypes. On the other hand, the income level of the father's influences the characteristics of the school the child goes. Children in a school with a good socio-cultural and economic level can be influenced by their peers' and their families' egalitarian attitudes and perspectives on. In addition, the curriculum and teachers in such schools may also be effective in improving the child's egalitarian perspective. Finally, in good income families, housework is done by neither mother nor father. In such families, housework is usually done by some people by salary. Therefore, the child may not see a difference in the sharing of housework between the mother and the father.

The following can be suggested in the light of the findings of the study:

- In this research we only studied with fathers and their child. Other researchers can make comparative studies involving both mothers and fathers.

- Relational studies can be conducted with children from diverse families (same sex parents, divorced and single parents etc.)

- More opportunities should be created for fathers to take care of their children. Working hours, maternity leave and legal rights should be arranged so that the fathers and mothers can provide care together.

- Children need to see a proper role model in reducing stereotypes. For this reason, parents can be directed to the appropriate model and exhibit non-sexist behavior.

- Family education programs can be organized to ensure families to question their gender stereotypes and how to reduce them.

- It may be advisable for the division of housework in the families can be equitable and for all household members can take responsibility.

- Equal responsibilities can be given to the children regardless of their gender.

- It may be advised remove gender stereotypes from cartoons, animated films and storybooks and give egalitarian perspective in them

\section{Notes}

This study was presented as oral presentation at the The 5th International Congress on Curriculum and Instruction (ICCI - 2017) in Mugla, Turkey on 26-28 October 2017

\section{REFERENCES}

[1] Aksoy, P., ve Baran, G. (2017). Annelerin cinsiyet rollerine ilişkin özellikleri ile çocukların oyuncak tercihleri ve oynadıkları oyun türleri arasındaki ilişki üzerine bir çalışma. Ĕ̈itimde Nitel Araştırmalar Dergisi- Journal of Qualitative Research in Education, 5(1), 102-136.

[2] Alpöge, G. ve Gündüz, E. (2001). Çocuğun Yaşamında Babanın Yeri ve Önemi, Aralık 2000 Sempozyum Raporu, Anne- Çocuk Eğitim Vakfi, yayın no: 12, Kansu Matbaacılık, İstanbul 
[3] Altınova, H. H. ve Duyan, V. (2013). Toplumsal Cinsiyet Algısı Ölçeğinin geçerlik ve güvenirlik çalışması. Toplum ve Sosyal Hizmet, 24(2), 9-22.

[4] Aydilek Çiftçi, M. (2011). Öğretmenlerin ve farklı sosyo-ekonomik düzeye sahip anne-babaların cinsiyet rolleri algisının 60-72 ay arası çocukların oyuncak tercihleri ve akran etkileșimleri ile ilișkisinin incelenmesi. (Yayınlanmamış Yüksek Lisans Tezi). Çukurova Üniversitesi, Adana.

[5] Barnard, K. and Solchany, J. (2002) Mothering, in M. Bornstein (ed.) Handbook of Parenting, Volume 3, pp. 3-26. Mahwah, NJ: Lawrence Erlbaum.

[6] Bee, H. \& Boyd, D.(2009). Çocuk gelişim psikolojisi (Çev. Ed. O. Gündüz). İstanbul: Kaknüs Yayınları

[7] Bianchi, S. M. 2000. Maternal employment and time with children: dramatic change or surprising continuity? Demography 37,401-14.

[8] Bonney, J.F., Kelley, M.L. \& Levent, R.F. (1999). A model of fathers' behavioral involvement in child care in dual-earner families. Journal of Family Psychology, 13(3), 401-415.

[9] Boyce, W. T., Essex, M. J., Alkon, A., Goldsmith, H. H., Kraemer, H. C., \& Kupfer, D. J. (2006). Early father involvement moderates biobehavioral susceptibility to mental health problems in middle childhood. Journal of the American Academy of Child and Adolescent Psychiatry, 45(12), 1510-1520.

[10] Bronte-Tinkew, J.; Carrano, J.; Horowitz, A. \& Kinukawa, A. (2008) Involvement among resident fathers and links to infant cognitive outcomes. Journal of Family Issues, 29(9). 1211-1244.

[11] Bronte-Tinkew, J.; Carrano, J. \& Guzman, L. (2006). Resident fathers' perceptions of their roles and links to involvement with infants. Fathering, 4(3). 254-285.

[12] Bronte-Tinkew, J., Moore, K., Capps, R., \& Zaff, J. (2006). Father involvement and youth transition into risky behaviors in immigrant and native-born families. Social Science Research, 35, 181-209.

[13] Bronte-Tinkew, J., Moore, K., \& Carrano, J. (2006). The father-child relationship, parenting styles, and youth risk behaviors. Journal of Family Issues, 27(6), 850-881.

[14] Burger, J.M. (2006). Kişilik. (Çev. Ed. İ. D. Erguvan Sarığlu). İstanbul: Kaknüs Yayınları.

[15] Carlson, M. J. (2006). Family structure, father involvement, and adolescent behavioral outcomes. Journal of Marriage and Family, 68,137-154.

[16] Cox, M. J., Owen, M. T., Henderson, V. K., \& Margand, N. (1992). The prediction of infant-father and infant-mother attachment. Developmental Psychology, 28, 474-483.

[17] Çelebi Öncü, E. ve Ünlüer, E. (2012). Preschoolers' views about gender related games and toys. Procedia - Social and Behavioral Sciences, 46, 5924 - 5927.

[18] Denham, S. A., Bassett, H., \& Wyatt, T. M. (2010). Gender differences in the socialization of preschoolers' social competence. New Directions for Child and Adolescent Development,128, 29-49. doi:10.1002/cd.267.
[19] Downer, J., Campos, R., McWayne, C., Gartner, T. (2008) Father involvement and children's early learning: A critical review of published empirical work from the past 15 years. Marriage and Family Review, 43, 67-108.

[20] Dubowitz, H., Black, M. M., Cox, C. E., Kerr, M. A., Litrownik, A. J.\& Runyan, D.K. (2001). Father involvement and children's functioning at age 6 years: A multisite study. Child Maltreatment, 6, 300-309.

[21] Easterbrooks, M. A., \& Goldberg, W. A. (1984) Toddler development in the family: Impact of father involvement and parenting characteristics. Child Development, 53, 740-752.

[22] Eisenberg, N.; Valiente, C.; Morris, A. S.; Fabes, R. A.; Cumberland, A.; Reiser, M., et al. (2003). Longitudinal Relations Among Parental Emotional Expressivity, Children's Regulation, And Quality of Socioemotional Functioning. Developmental Psychology, 39, 2 - 19.

[23] Endendijk, J. J., Groeneveld, M. G., van Berkel, S. R., Hallers-Haalboom, E. T., Mesman, J., \& Bakermans Kranenburg, M. J. (2013). Gender stereotypes in the family context: Mothers, fathers, and siblings. Sex Roles, 68, 577590. doi:10.1007/s11199-013-0265-4

[24] Erdoğan, A. (2004). Çocuğun psikososyal gelişimde babanın rolü. Yeni Symposium, 42. 147-153

[25] Fagot, B. I. \& Hagan, R. (1991). Observations of parent reactions to sex stereotyped behaviors: age and sex effeets. Child Development, 62, 617-628.

[26] Fagot, B. I., \& Leinbach, M. D. (1995). Gender knowledge in egalitarian and traditional families. Sex Roles, 32, 513 526.

[27] Flouri, E. (2008). Fathering and adolescents' psychological adjustment: The role of fathers' involvement, residence and biology status. Child: Care, Health and Development, 34(2), 152-161.

[28] Flouri, E., \& Buchanan, A. (2004). Early father's and mother's involvement and child's later educational outcomes. British Journal of Educational Psychology, 74, 141-153.

[29] Freeman, N. K. (2007). Preschoolers' perceptions of gender appropriate toys and their parents' beliefs about genderized behaviors: miscommunication, mixed messages, or hidden truths?. Early Childhood Education Journal, 34(5), 357-366.

[30] Güney, O. (2012). 5-6 yaş çocuklarında algllanan cinsiyet kalipyargilarına ilişkin ebeveyn beklentileri ile oyuncak tercihleri arasındaki ilişki. (Yayınlanmamış Yüksek Lisans Tezi). Maltepe Üniversitesi, İstanbul.

[31] Gjerdingen, D. K., Froberg, D. G., \& Fontaine, P. (1991). The effects of social support on women's health during pregnancy, labor, and delivery, and the postpartum period. Family Medicine, 23, 370-375.

[32] Goodman, J. H. (2004). Becoming an Involved Father of an Infant. Journal of Jognn in Review, 34(2): 190-200.

[33] Gültekin Akduman, G. ve Türkoğlu, D. (2013). Okul öncesi dönem çocuğu olan babaların babalık rollerini algılamaları ile çocuklarının davranış problemleri arasındaki ilişkinin incelenmesi. Uluslararası Hakemli Aile Çocuk ve Eğitim Dergisi, 1 (1). 1-17. 
[34] Hofferth, S. L. (2003). Race/ethnic differences in father involvement in two-parent families: Culture, context, or economy? Journal of Family Issues, 23. 1-32.

[35] Hupp, J.M.; Smith. J.L.; Coleman, J.M. \& Brunel, A.M. (2010). That's a boy's toy: Gender-typed knowledge in toddlers as a function of mother's marital status. The Journal of Genetic Psychology, 171(4), 389-401.

[36] Karre, J.K. (2016). Gender-based attitudes and father involvement: amount, assessment, and desires for more. Fathering, 13(3). 231-144.

[37] Kato, K., Ishii-Kuntz, M., Makino, K., \& Tsuchiya, M. (2002). The impact of paternal involvement and maternal childcare anxiety on sociability of three-year-olds: Two cohort comparisons. Japanese Journal of Developmental Psychology, 13 (1), 30-41.

[38] Kuzucu, Y. (2011). Değişen babalık rolü ve çocuk gelişimine etkisi. Türk Psikolojik Danışma ve Rehberlik Dergisi, 4 (35), 79-91.

[39] Kuruçırak, Ş. (2010). 4-12 Aylık Bebeği Olan Babaların, Babalı Rolü Algısı Ile Bebek Bakımına Katılımı Arasındaki İlişki. (Yayımlanmış Yüksek Lisans Tezi). Akdeniz Üniversitesi, Antalya

[40] Lam, V.L. \& Leman, P.J. (2003). The influence of gender and ethnicity on children's inferences about toy choice. Social Development, 12(2), 269-287.

[41] Lindsey, L. L. (2016). Gender roles: a sociological perspective. (6th. Ed). Routledge, USA.

[42] Maccoby, E. E. (2002). Gender and group process: A developmental perspective. Current Directions in Psychological Sciences, 11, 54-58.

[43] Manlove E.E.; Vernon-Feagans, L. (2002). Caring for infant daughters and sons in dual earner households: Mother reports of father involvement in weekday time and tasks. Infant and Child Development, 11, 305-320.

[44] Marsiglio, W., Amato, P., Day, R. \& Lamb, M. (2000). Scholarship on fatherhood in the 1990s and beyond. Journal of Marriage and the Family, 62,1173-1191.

[45] McHale, S. M., Crouter, A. C. \& Whiteman, S. D. (2003). The family contexts of gender development in childhood and adolescence. Social Development, 12, 125-148.

[46] Murray, T.L. (2004). Constructions of gender: comparing the perceptions of children from traditional vs. egalitarian families. (Unpublished Doctoral Dissertation). Institute of Advanced Psychological Studies Adelphi University.

[47] Nosek, B. A., Benaji, M. R., \& Greenwald, A. G. (2002). Harvesting implicit group attitudes and beliefs from a demonstration web site. Group Dynamics: Theory, Research, and Practice, 6, 101-115. doi:10.1037/1089-2699.6.1.101.

[48] Peris, T. S., Goeke-Morey, M. C., Cummings, E. M., \& Emery, R. E. (2008). Marital conflict and support seeking by parents in adolescence: Empirical support for the parentification construct. Journal of Family Psychology, 22, 633-642. doi:10.1037/a0012792

[49] Parke, R. D. (2004). Fathers, families, and the future: A plethora of plausible predictions. Merrill-Palmer Quarterly, 50(4). 456-470.

[50] Pruett, K. D. (1997). How men and children affect each other's development. Zero to Three, 18 (1), 3- 11.

[51] Raag, T. \& Rackliff, C.L. (1998). Preschoolers' awareness of social expectations of gender: relationships to toy choices. Sex Roles, 38, 685- 700 .

[52] Radin, N. \& Harold-Goldsmith, R. (1989). The Involvement of Selected Unemployed and Employed Men with Their Children. Child Development, 60 (2), 454-459.

[53] Raley, S. \& Bianchi, S. (2006). Sons, Daughters and Family Processes. Does Gender of Children Matter? Annual Review of Sociology, 32, 401-421.

[54] Rina, E.M., \& Feinberg, M.E. (2012). Involvement in child-rearing and mothers' and fathers' adjustment. Family Relations, 61, 836-850.

[55] Rohner, R. P., \& Veneziano, R. A. (2001). The importance of father love: History and contemporary evidence. Review of General Psychology, 5(4), 382-405.

[56] Rowe, M. L., Cocker, D., \& Pan, B. A. (2004). A comparison of fathers' and mothers' talk to toddlers in low-income families. Social Development, 13, 278-291.

[57] Sandberg, J.F., \& Hofferth, S. (2001) Changes in Children' s Time with Parents: United States, 1981-1997. Demography, 38(3): 423-436.

[58] Sandnabba, N.K. \& Ahleberg, C. (1999). Parents' attitudes and expectations about children's cross-gender behavior. Sex Roles, 40(3/4), 249-262.

[59] Shannon, J. D., Tamis-LeMonda, C. S., \& Cabrera, N. (2006). Fathering in infancy: Mutuality and stability between 6 and 14 months. Parenting, 6, 167-188.

[60] Sımsıkı, H. ve Şendil, G. (2014). Baba Katılım Ölçeği' nin geliştirilmesi. Elektronik Sosyal Bilimler Dergisi, 13(49), 104-123.

[61] Storey, A.E., Walsh, C.J., Quinton, R.L., \& Wynne-Edwards, K.E. (2000). Hormonal correlates of paternal responsiveness in new and expectant fathers. Evolution and Human Behavior, 21, 79-95.

[62] Strauss, R. S., \& Knight, J. (1999). Influence of the home environment on the development of obesity in children. Pediatrics, 103(6).

[63] Suess, G. J., Grossman, K. E., \& Sroufe, L. A. (1992). Effects of infant attachment to mother and father on quality of adaption to preschool: From dyadic to individual organization of self. International Journal of Behavioral Development, 15, 43-65.

[64] Super, C. M. \& Harkness, S. (1996). The cultural structuring of child development. In J. W. Berry, P. R. Dasen \& T. S. Saraswathi (Eds.), Handbook of Cross-cultural psychology, Vol. 2: Basic processes and human development (2nd ed, pp. 1-39). Boston, MA: Allyn \& Bacon.

[65] Şıvgın, N. (2015). Cinsiyet rolleri ĕgitim etkinliklerinin anasinifina devam eden 60-72 aylık çocukların toplumsa cinsiyet kalipyargllarına etkisnin incelenmesi. 
(Yayınlanmamıș Doktora Tezi). Gazi Üniversitesi, Ankara, Türkiye.

[66] Tamis-LeMonda, C. S., \& Cabrera, N. (2002). (Eds.). Handbook of father involvement: Multidisciplinary perspectives. Mahwah, NJ: Lawrence Erlbaum Associates

[67] Tamis-LeMonda, C. S., Kahana-Kalman, R., \& Yoshikawa, H. (2009). Father involvement in immigrant and ethnically diverse families from the prenatal period to the second year: Prediction and mediation mechanisms. Sex Roles, 60, 496-509.

[68] Tenenbaum, H., \& Leaper, C. (2002). Are parents' gender schemas related to their children's gender-related cognitions? A meta-analysis. Developmental Psychology, 38(4), 615-630. doi:10.1037/0012-1649.38.4.615

[69] Telli, A.A. (2014). 3-6 Yaş Grubu Çocuğu Olan Babaların Babalık Rolü Algısı Ve Etkileyen Faktörlerin Belirlenmesi. (Yayınlanmamış Yüksek Lisans Tezi). Atatürk Üniversitesi, Erzurum.

[70] Trindade, Z. A., \& Menandro, M. C. S. (2002). Teenage fathers: Life experience and signification. Estudos de Psicologia, 7(1), 15-23.

[71] Updegraff, K.A., Perez-Brena, N.J., Baril, M.E., McHale, S.M., \& Umana-Taylor, A.J. (2012). Mexican-origin mothers' and fathers' involvement in adolescents' peer relationships: A pattern-analytic approach. Journal of Marriage and Family, 74, 1069-1083.

[72] Ünlü Çetin, Ş. (2015). Father Involvement In Early Years: Comparing Children's Perceptions Of Father Involvement With Those Of Their Fathers' And Mothers'. (Yayınlanma mış Yüksek Lisans Tezi). Ortadoğu Teknik Üniversitesi, Ankara.

[73] Volling, B. L., \& Belsky, J. (1992). The contribution of mother-child and father-child relationships to the quality of sibling interaction: A longitudinal study. Child Development, 63, 1209-1222.
[74] Weisgram, E.S.; Fulcher, M. \& Dinella, L.M. (2014). Pink gives girls permission: Exploring the roles of explicit gender labels and gender-typed colors on preschool children's toy preferences. Journal of Applied Developmental Psychology, 35. 401-409.

[75] Wilson, C.M. (1996). Exploring Preschoolers' Conceptions Of Gender. (Unpublished Master Thesis). San Jose State University.

[76] Wood, E.; Desmarais, S. \& Gugula, S. (2002). The impact of parenting experience on gender stereotyped toy play of children. Sex Roles, 47(1/2), 39-49.

[77] Yağan Güder, S. (2014). Okul Öncesi Dönemdeki Çocukların Toplumsal Cinsiyet Algılarının İncelenmesi. (Yayınlanmamış doktora tezi). Hacettepe Üniversitesi, Ankara.

[78] Yağan Güder, S. ve Güler Yıldız, T. (2016). Okul öncesi dönemdeki çocukların toplumsal cinsiyet algılarında ailenin rolü. Hacettepe Üniversitesi Ë̆itim Fakültesi Dergisi, 31(2), 424-446.

[79] Yağan Güder, S. ve Alabay, E. (2016). 3-6 Yaş Arasındaki Çocukların Oyuncak Tercihlerinin Toplumsal Cinsiyet Bağlamında İncelenmesi. Ahi Evran Üniversitesi Kırşehir Eğitim Fakültesi Dergisi, 17(2). 91-111.

[80] Y1ld1z, F. Ü. \& Kay1l1, G.(2014). An investigation of preschool children's toy preferences according to different variants. International Conference on Global Trends in Academic Research, June2-3, 2014, Bali, Indonesia.

[81] Yogman, M. W. Kindlon, D., \& Earls, F. (1995). Fathe in volvement and cognitive/behavioral outcomes of preterm infants. Journal of the American Academy of Child and Adolescent Psychiatry, 34, 58-66.

[82] Zeybekoğlu, Ö. (2013). Günümüzde Erkeklerin Gözünden Babal1k ve Aile. Mediterranean Journal of Humanities. III/2, 297-328. 